Article

\title{
Evaluating Growth, Yield, and Water Use Efficiency of African and Commercial Ginger Species in South Africa
}

\author{
Auges Gatabazi ${ }^{1, *}$, Diana Marais ${ }^{1}$, Martin J. Steyn ${ }^{1}{ }^{1}$, Hintsa T. Araya ${ }^{2}{ }^{(\mathbb{B}}$, \\ Motiki M. Mofokeng ${ }^{2}$ (D) and Salmina N. Mokgehle ${ }^{2}$ \\ 1 Department of Plant and Soil Sciences, University of Pretoria, Pretoria 0002, South Africa; \\ Diana.Marais@up.ac.za (D.M.); Martin.Steyn@up.ac.za (M.J.S.) \\ 2 Agricultural Research Council, Vegetable and Ornamental Plant (VOP), Private Bag X293, Pretoria 0001, \\ South Africa; Arayah@arc.agric.za (H.T.A.); MofokengM@arc.agric.za (M.M.M.); \\ MokgehleNS1@arc.agric.za (S.N.M.) \\ * Correspondence: auges2012@gmail.com
}

Received: 28 November 2018; Accepted: 12 March 2019; Published: 16 March 2019

\begin{abstract}
Ginger species play an important economic role as medicinal plants, food flavourings, and dietary supplements. Products from ginger, including oil and fresh and dried rhizomes can be used to treat malaria, asthma, headaches, and act as anti-inflammatory and anti-microbial agents. The cultivation of wild plant species can alleviate the pressure from harvesting from the wild. Under cultivation, the major constraints on crop yield and quality are water availability and plant nutrition. Therefore, the impact of water stress on commercial and African ginger was assessed in the rain shelter study. Irrigation treatments were based on the maximum allowable depletion (MAD) levels of plant available water in the root zone (T1: 20-25\% MAD, the control; T2: 40-45\% MAD; T3: 60-65\% MAD; T4: 80-85\% MAD). As water stress decreased, the plant height and number of stems per plant of both plant species were positively affected. The number of open stomata was higher for well-watered and less stressed treatments in both ginger species. Higher fresh and dry rhizome yields were recorded for commercial ginger at all water treatments as compared to those from African ginger. In general, water use efficiency (WUE) of fresh and dry rhizome yield was higher for commercial ginger as compared to the indigenous African ginger, while moderately stressed treatments generally resulted in the highest WUE for both species.
\end{abstract}

Keywords: Africa ginger; commercial ginger; growth; yield; irrigation; water use efficiency

\section{Introduction}

South Africa is characterised by flora that is well known for its abundance in aromatic compounds, however, currently about 2576 plant species are threatened with extinction due to over-harvesting from the wild [1]. This includes some species in the genus Zingiber, which belong to the family Zingiberaceae [2], with African (Siphonochilus aethiopicus) and commercial ginger (Zingiber officinale) belonging to the family. This genus is one of the largest genera, comprising of perennial ornamentals and aromatic herbs that are cultivated for valuable medicines [3]. African and commercial gingers are considered to be important traditional medicinal plants in southern Africa, being used for treatment of a variety of human aliments [4]. Products, including oil and fresh and dried rhizomes can be used to treat malaria, asthma, headaches, and act as anti-inflammatory and anti-microbial agents [5]. The trade in traditional medicines in South Africa is estimated to be worth R2.9 billion (201 billion USD) per year [6]. In South Africa, the plant trade serves as a key in the rural industry and business incubators, with 771 species being harvested from the wild for sale. The production of commercial ginger is well 
documented in different parts of the world [7]. African ginger was identified as one of the species with commercial production potential, in South Africa. It was estimated that 1.9 tonnes of African ginger, totaling a number of 52,000 plants, is annually traded in South Africa and the current situation necessitates an alternative supply of ginger plant material to meet the demand [4].

With climate change (increased risk of drought) and the slow growing capabilities of some wild ginger species, the threat of extinction of these species is high and it has become urgent for research to address the strategies of improving ginger species yield through improved cultivation technologies.

Water is one of the essential role players in crop production that affect crop yield. Water availability can also affect quality and earlier reports have shown that drought stress can increase the concentration of secondary metabolites in different plants and some medicinal plants, including ginger [8,9]. The incidences of drought in many sub-Saharan growing areas due to the negative effects of climate change restrict the growth and photosynthetic activities of crops [10]. Water shortage affects crops according to crop growth stages and physiological plants processes. Beside physiological responses, plants also undergo morphological alterations, causing changes in the distribution of assimilates, which can reduce vegetative growth and hinder the development of plant reproductive organs [11]. According to Galmés at al. [12], the ability of plants to survive under varying stressed conditions depends on growth stage, intensity of water deficit, plant species, and duration. Crop species growing under variable water supply, especially during yield formation stages, can still produce optimum yields with maximum water use efficiency (WUE) [13]. There is limited information available on the response of ginger species that are subjected to varying water stress regimes. Information regarding the plant's response to water stress regimes and drought tolerance mechanisms can help to devise appropriate irrigation management strategies and be useful in breeding programmes for the selection of genotypes that can withstand extreme conditions. Several studies have reported on the role of medicinal plants as agents with anti-microbial and anti-inflammatory properties, and some are used for treating various ailments. Ghasemzadeh et al. [14] indicated the medicinal potential of Malaysia ginger (Z. officinale) varieties through their high antioxidant activities, as well as the total contents of phenolic compounds and flavonoids. Additionally, numerous experimental studies on the growth and yield response of medicinal plants have been investigated. Wilson and Ovid [15] assessed the growth and yield responses of ginger (Z. officinale Roscoe), as affected by shade and fertilizer applications. Jasim et al. [16] reported that plant growth promoting products had considerable effects on the growth of ginger. A field study on nitrogen and water management reported higher leaf area index (LAI) under well-watered treatments for Perlagonium sidoides [17]. Although several studies have reported on the medicinal potential of ginger species, yield, and plant response to growth regulators, there is still limited information available on the response of ginger to water supply, which may significantly affect growth, yield, and quality. Furthermore, there is virtually no published information on the cultivation of African ginger. Therefore, the aim of this study was to examine the response of commercial and African ginger to water stress by evaluating their water use, growth, yield, and water use efficiency.

\section{Materials and Methods}

\subsection{Experimental Site}

The experiment was conducted under a rain shelter at the Hatfield Experiential Farm of the University of Pretoria, Hillcrest campus, Pretoria, South Africa. The experiment was completed during the $2015 / 2016$ and $2016 / 2017$ cropping seasons. The area is located at $25^{\circ} 45^{\prime} \mathrm{S}$ and $28^{\circ} 16^{\prime} \mathrm{E}$, with an elevation of $1350 \mathrm{~m}$ above sea level.

\subsection{Soil Analysis and Fertilizer Application}

Soil samples were randomly taken from depths of 0-20 cm, 20-40 cm, 40-60 cm, and 60-80 cm to assess chemical and physical properties (Tables 1 and 2). The soil of the experiment site was characterised as a sandy clay loam of the Hutton [18], form with clay content of $36 \%$ at $0-20 \mathrm{~cm}$ soil 
depth (Table 2). Based on the soil sample analysis, phosphorus was applied as basal application at planting at a rate of $170 \mathrm{~kg} \mathrm{P} \mathrm{ha}^{-1}$ (as Superphosphate $8.3 \%$ ), while nitrogen and potassium were applied at rates of $220 \mathrm{~kg} \mathrm{ha}^{-1}$ (LAN 28\%) and $170 \mathrm{~kg} \mathrm{ha}^{-1}(\mathrm{KCl} 50 \%)$, respectively, for both ginger species. The $\mathrm{N}$ and $\mathrm{K}$ were applied in split applications of equal amounts at 45 and 90 days after planting. Weather data was obtained from an automatic weather station at the Hatfield Experimental Farm (Table 3).

Table 1. Chemical properties of different soil layers of the experimental field site.

\begin{tabular}{|c|c|c|c|c|}
\hline \multirow{2}{*}{ Chemical Properties } & \multicolumn{4}{|c|}{ Soil Depth (cm) } \\
\hline & $0-20$ & $20-40$ & $40-60$ & $60-80$ \\
\hline $\mathrm{pH}\left(\mathrm{H}_{2} \mathrm{O}\right)$ & 6.3 & 6.6 & 6.8 & 6.9 \\
\hline $\mathrm{EC}\left(\mathrm{mS} \mathrm{m}^{-1}\right)$ & 64 & 66 & 28 & 26 \\
\hline $\mathrm{CEC}\left(\mathrm{cmol}(+) \mathrm{kg}^{-1}\right)$ & 14.7 & 10.2 & 9.7 & 10.7 \\
\hline Organic matter content $(\%)$ & 0.9 & 0.8 & 0.7 & 0.7 \\
\hline Total $\mathrm{N}\left(\mathrm{mg} \mathrm{kg}^{-1}\right)$ & 19.6 & 14.6 & 14.3 & 13 \\
\hline Available P (mg kg $\left.{ }^{-1}\right)$ & 44.6 & 43.8 & 4.3 & 2.3 \\
\hline Available $\mathrm{K}\left(\mathrm{cmol}(+) \mathrm{kg}^{-1}\right)$ & 0.95 & 0.12 & 0.09 & 0.07 \\
\hline
\end{tabular}

Table 2. Physical properties of different soil layers of the experimental field site.

\begin{tabular}{|c|c|c|c|c|c|c|}
\hline \multirow{2}{*}{$\begin{array}{l}\text { Soil Depth } \\
\text { (cm) }\end{array}$} & \multicolumn{3}{|c|}{$\begin{array}{c}\text { Particle Size } \\
(\%)\end{array}$} & \multirow{2}{*}{$\begin{array}{l}\text { Bulk Density } \\
\qquad\left(\mathrm{g} \mathrm{cm}^{-3}\right)\end{array}$} & \multirow{2}{*}{$\begin{array}{c}\text { FC Weight } \\
(\%)\end{array}$} & \multirow{2}{*}{$\begin{array}{c}\text { PWP Weight } \\
(\%)\end{array}$} \\
\hline & Clay & Silt & Sand & & & \\
\hline $0-20$ & 36.0 & 2.0 & 62.0 & 1.1 & 0.280 & 0.159 \\
\hline $20-40$ & 36.0 & 8.0 & 56.0 & 1.1 & 0.302 & 0.182 \\
\hline $40-60$ & 46.0 & 4.0 & 50.0 & 1.0 & 0.326 & 0.206 \\
\hline $60-80$ & 44.0 & 8.0 & 48.0 & 1.0 & 0.331 & 0.213 \\
\hline
\end{tabular}

Where: FC: Soil moisture at field capacity; PWP: Permanent wilting point.

Table 3. Monthly mean weather data for an automatic weather station at the Hatfield Experimental Farm.

\begin{tabular}{|c|c|c|c|c|c|c|c|c|}
\hline \multirow{2}{*}{$\begin{array}{c}\text { Month } \\
2015 / 2016\end{array}$} & \multicolumn{2}{|c|}{ Temperature $\left({ }^{\circ} \mathrm{C}\right)$} & \multicolumn{2}{|c|}{$\begin{array}{l}\text { Relative Humidity } \\
(\%)\end{array}$} & \multirow[t]{2}{*}{ 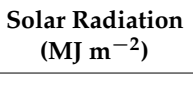 } & \multirow[t]{2}{*}{$\begin{array}{l}\text { Wind Speed } \\
\quad\left(\mathrm{m} \mathrm{s}^{-1}\right)\end{array}$} & \multirow[t]{2}{*}{$\begin{array}{l}\text { Daily ETo } \\
(\mathrm{mm})\end{array}$} & \multirow[t]{2}{*}{$\begin{array}{l}\text { Total Rainfall } \\
\text { (mm) }\end{array}$} \\
\hline & Max & Min & Max & Min & & & & \\
\hline November & 31.3 & 15.3 & 56.0 & 9.1 & 19.7 & 2.3 & 6.4 & 22.2 \\
\hline December & 32.9 & 15.3 & 62.0 & 12.9 & 19.7 & 1.9 & 6.1 & 51.7 \\
\hline January & 30.3 & 17.7 & 66.0 & 21.1 & 18.0 & 1.8 & 5.3 & 43.6 \\
\hline February & 32.1 & 17.9 & 65.7 & 17.8 & 18.6 & 1.6 & 5.4 & 22.1 \\
\hline March & 29.2 & 16.2 & 66.9 & 21.6 & 15.1 & 1.2 & 3.9 & 16.5 \\
\hline April & 27.7 & 12.7 & 68.6 & 18.3 & 14.4 & 1.4 & 3.7 & 0.6 \\
\hline May & 22.3 & 8.4 & 69.8 & 20.4 & 11.1 & 1.4 & 2.7 & 1.6 \\
\hline June & 20.6 & 5.8 & 68.5 & 20.4 & 10.4 & 1.2 & 2.3 & 0.4 \\
\hline July & 20.7 & 5.8 & 61.9 & 12.9 & 10.9 & 1.4 & 2.7 & 0.1 \\
\hline August & 20.2 & 4.3 & 66.9 & 10.2 & 12.9 & 1.6 & 3.2 & 0.0 \\
\hline \multicolumn{9}{|l|}{$2016 / 2017$} \\
\hline November & 28.7 & 15.7 & 68.5 & 22.4 & 15.4 & 2.0 & 4.8 & 25.4 \\
\hline December & 29.7 & 16.9 & 69.3 & 22.8 & 17.5 & 1.9 & 5.2 & 62.1 \\
\hline January & 28.6 & 16.6 & 71.8 & 26.7 & 17.0 & 1.8 & 4.8 & 66.3 \\
\hline February & 27.9 & 17.1 & 71.1 & 30.5 & 14.1 & 1.8 & 4.2 & 32.1 \\
\hline March & 29.0 & 14.4 & 70.2 & 17.7 & 15.8 & 1.7 & 4.4 & 22.4 \\
\hline April & 31.8 & 15.3 & 62.9 & 12.5 & 15.0 & 2.3 & 4.0 & 12.9 \\
\hline May & 20.2 & 5.8 & 84.8 & 30.7 & 24.2 & 1.1 & 4.1 & 3.1 \\
\hline June & 21.3 & 5.8 & 87.2 & 30.9 & 21.0 & 1.5 & 3.2 & 1.5 \\
\hline July & 22.0 & 5.9 & 83.1 & 28.1 & 19.2 & 1.5 & 3.2 & 0.5 \\
\hline August & 25.1 & 7.8 & 70.2 & 23.7 & 19.6 & 2.1 & 4.2 & 0.0 \\
\hline
\end{tabular}

Where: Max: maximum, Min: minimum; ETo: daily reference evapotranspiration.

\subsection{Experimental Layout and Treatments}

The experiment was laid out in a randomized complete block design (RCBD) with two ginger species, four irrigation regimes, and three replicate blocks. Each experimental plot was $4 \mathrm{~m}^{2}$ $(2.0 \mathrm{~m} \times 2.0 \mathrm{~m})$ in size, with eight plant rows per plot, and $1 \mathrm{~m}$ spaces between the blocks. The spacing 
between plant rows was $0.25 \mathrm{~m}$ and $0.25 \mathrm{~m}$ within rows, giving a plant population of 64 plants per $4 \mathrm{~m}^{2}\left(160,000 \mathrm{ha}^{-1}\right)$, and the two ginger species used were commercial (Z. officinale) and African ginger (S. aethiopicus). The water treatments were as follows:

- Irrigation treatment 1 (T1-Control): Soil refilled to field capacity when 20-25\% of available soil water (ASW) was depleted.

- Irrigation treatment 2 (T2): Refilled to field capacity when $40-45 \%$ of ASW was depleted.

- Irrigation treatment 3 (T3): Refilled to field capacity when $60-65 \%$ of ASW was depleted.

- Irrigation treatment 4 (T4): Refilled to field capacity when $80-85 \%$ of ASW was depleted.

The eight treatment combinations are presented in Table 4.

Table 4. Ginger $\times$ Irrigation treatment combinations used in the experiment.

\begin{tabular}{ccc}
\hline No & Treatment & Description \\
\hline 1 & CG + T1 & Commercial ginger + 20-25\% MAD \\
2 & CG + T2 & Commercial ginger + 40-45\% MAD \\
3 & CG + T3 & Commercial ginger + 60-65\% MAD \\
4 & CG + T4 & Commercial ginger + 80-85\% MAD \\
5 & $\mathrm{AG}+\mathrm{T} 1$ & African ginger + 20-25\% MAD \\
6 & $\mathrm{AG}+\mathrm{T} 2$ & African ginger $+40-45 \%$ MAD \\
7 & $\mathrm{AG}+\mathrm{T} 3$ & African ginger $+60-65 \%$ MAD \\
8 & $\mathrm{AG}+\mathrm{T} 4$ & African ginger $+80-85 \%$ MAD \\
\hline
\end{tabular}

Where: CG: Commercial ginger; AG: African ginger; MAD: Maximum allowable depletion.

\subsection{Planting Material Collection and Trial Establishment}

Commercial and African ginger rhizomes were acquired from Fortuna Company and Agricultural Research Council (ARC) in South Africa, respectively. The rhizomes of both the plant species were stored for three months at temperature of $12{ }^{\circ} \mathrm{C}$ to 14 until they were transplanted into the field. The obtained ginger rhizome sizes ranged from 20 to $30 \mathrm{~g}$ and they were planted by hand at a depth of $7 \mathrm{~cm}$ during the 2015/2016 and 2016/2017 seasons. General pest and disease management practices were followed when necessary. Weed management was manually done throughout the growing season.

\subsection{Soil Water Content Monitoring and Irrigation Scheduling}

A 503DR CPN Hydro Probe neutron water meter (Campbell Pacific Nuclear, California, USA) that was calibrated for the experimental site was used to measure the soil water content. Access tubes were installed in the middle of each plot and readings were taken at $0.2 \mathrm{~m}$ intervals to a depth of $0.8 \mathrm{~m}$.

Irrigation scheduling was based on the measured depletion of available soil water (ASW). The ASW was considered as the difference between root zone water storage at field capacity and the permanent wilting point. The effective root zone of ginger plants was estimated to be $0.40 \mathrm{~m}$, and although water contents to a depth of $0.8 \mathrm{~m}$ were recorded, irrigation was based on ASW depletion of the effective root zone. The depleted percentage of ASW $\left(\theta_{d}\right)$ was calculated using Equation (1) [19].

$$
\text { Depletion of avalable soil water }=100 \frac{1}{n} \sum_{1}^{n} \frac{F C_{i}-\theta_{i}}{F C_{i}-P W P_{i}}
$$

where $n$ is the number of layers of the actual rooting depth used in the soil water content measurement, $F C_{i}$ is the soil water content at field capacity for $i$ th layer, $\theta_{i}$ is the soil water content in $i$ th layer, and $P W P_{i}$ is the soil water content at permanent wilting point on volume basis.

\subsection{Growth Parameters}

Data on growth was collected on a monthly basis and eight plants were randomly selected and tagged as data plants. Parameters, including plant height, number of stems per plant, and number of leaves per plant were measured every month from 100 days after planting to 240 days after planting. 
Leaf area index and canopy interception of photosynthetically active radiation $\mathrm{FI}_{\text {PAR }}$ were measured once a month while using a ceptometer (Accupar model LP-80, Decagon Devices Inc., Pullman, WA, USA). PAR measurements were collected from above and below the canopy. In order to calculate the fractional interception (FI) of PAR, the ratio between the above canopy and below canopy PAR measurement was used, as indicated in Equation (2) [20]:

$$
F I_{\text {PAR }}=1-\left(\frac{\text { PAR below canopy }}{\text { PAR above canopy }}\right)
$$

\subsection{Yield Parameters}

Data on yield parameters was collected at 240 days after planting. The plants from each plot were carefully dug up and the rhizomes were separated from leaves and stems. Fresh rhizome mass was measured directly after harvest and dry matter yield was determined after the separated rhizomes, leaves, and stems were oven dried at $50{ }^{\circ} \mathrm{C}$ for $72 \mathrm{~h}$.

\subsection{Water Use and Water Use Efficiency}

Crop water use or evapotranspiration $(E T)$ was determined by using the soil water balance of equation [21], as follows:

$$
E T=I+P-D-R-\Delta S
$$

where, ET refers to crop water use/crop evapotranspiration $(\mathrm{mm}), I$ represents irrigation $(\mathrm{mm}), P$ represents precipitation $(\mathrm{mm}), D$ refers to drainage $(\mathrm{mm}), R$ is the surface runoff $(\mathrm{mm})$, and $\Delta S$ is change in soil water storage between planting and harvest $(\mathrm{mm})$. Runoff and drainage were assumed to be negligible, as irrigation was carefully managed to prevent over irrigation or runoff and rain was excluded by the rain shelter.

Water-use efficiency (WUE) was calculated as yield divided by volume of irrigation water used, using the following equation [21];

$$
\mathrm{WUE}=\frac{Y}{\sum E T}
$$

where, WUE is the water use efficiency in $\mathrm{kg} \mathrm{ha}^{-1} \mathrm{~mm}^{-1}, Y$ represents the yield in $\mathrm{kg} \mathrm{ha}^{-1}$, and $\sum E T$ is the total seasonal water use in $\mathrm{mm}$.

\subsection{Scanning Electron Microscopy (SEM) Parameters}

The response of the plants to irrigation regimes in terms of stomata number and the number of open stomata were collected and analysed from scanning electron microscope images, following the method that was described by [22], with slight modifications. A leaf sample $(10 \mathrm{~mm} \times 10 \mathrm{~mm})$ was cut from the third leaf from the top of the plant and then fixed in $3 \% \mathrm{w} / \mathrm{v}$ aqueous solution glutaraldehyde ( $0.05 \mathrm{M}$ phosphate buffer at $\mathrm{pH} 7.0)$ immediately after cutting. The samples were then thoroughly rinsed with distilled water and the procedure was repeated three times. Thereafter, the samples were post fixed in osmium tetroxide $(1 \% \mathrm{~m} / \mathrm{v})$ and incubated for two hours. Samples were further dehydrated in a series of ethanol concentrations of 30, 50, 70, 90, and $100 \%(\mathrm{~m} / \mathrm{v})$ for $15 \mathrm{~min}$ and then dried in a critical point drying apparatus (Bio-Rad E300, Watford, UK). The dried samples were mounted on copper stubs and coated with gold in a vacuum coating unit (Polaron E5200C, Watford, UK). The samples were then observed under a JSM 840 scanning electron microscope (JEOL, Tokyo, Japan) at $350 \times$ magnification. Total number and number of open stomata were counted at $350 \times$ magnification.

\subsection{Statistical Analysis}

The data was subjected to analysis of variance by using Statistical Analysis System software (SAS) version 9.4 (Cary, NC, USA). The means were separated and then compared using the least significant 
difference (LSD) test at $5 \%$ probability. Correlations among the parameters were constructed while using Microsoft Excel 2010.

\section{Results and Discussion}

\subsection{Soil Water Used}

The amounts of water that were used by each treatment of the two ginger species during the 2015/2016 and 2016/2017 growing seasons are presented in Table 5. The data showed that there were significant differences among water treatments, but the ginger species did not significantly differ in water use for the same treatments within a specific season. The results are clear that, for both commercial and African ginger, the well-watered treatment (20-25\% MAD) showed significantly higher water use when compared to other treatments in both years. Water use significantly decreased with increase in water stress level for both species in the first season $(2015 / 2016$; Table 5). The obtained data indicate that both ginger species showed no significant differences in water use between treatments $40-45 \%, 60-65 \%$, and 80-85\% MAD during the second season (2016/2017; Table 5). Soil water uptake can vary widely with season, management practices, location, and crop varieties. During 2016/2017, substantially more water was depleted for all of the stress treatments, as compared to 2015/2016. This could possibly be explained by more rapid canopy development early in the 2016/2017 season (higher FI values when water treatments commenced; which resulted in higher total water use amounts.

Table 5. Total water use during the growing season of two ginger species subjected to different irrigation regimes.

\begin{tabular}{cccc}
\hline \multirow{2}{*}{ Ginger Species } & \multicolumn{2}{c}{ Water Use (mm) } \\
\cline { 2 - 4 } & MAD (\%) & $\mathbf{2 0 1 5 / 2 0 1 6}$ & $\mathbf{2 0 1 6 / 2 0 1 7}$ \\
\hline \multirow{2}{*}{ CG } & $20-25$ & $469^{\mathrm{a}}$ & $549^{\mathrm{a}}$ \\
& $40-45$ & $284^{\mathrm{b}}$ & $362^{\mathrm{bc}}$ \\
& $60-65$ & $176^{\mathrm{c}}$ & $344^{\mathrm{bc}}$ \\
& $80-85$ & $109^{\mathrm{d}}$ & $329^{\mathrm{c}}$ \\
& $20-25$ & $462^{\mathrm{a}}$ & $543^{\mathrm{a}}$ \\
\hline \multirow{2}{*}{ AG } & $40-45$ & $275^{\mathrm{b}}$ & $381^{\mathrm{b}}$ \\
& $60-65$ & $183^{\mathrm{c}}$ & $363^{\mathrm{bc}}$ \\
& $80-85$ & $117^{\mathrm{d}}$ & $341^{\mathrm{bc}}$ \\
\hline Lsd & - & 25.6 & 48.1 \\
\hline
\end{tabular}

Where: CG: Commercial ginger, AG: Africa ginger. MAD: maximum allowable depletion of plant available soil water. * Note: values followed by the same letter do not differ significantly at $\mathrm{P}=0.05$.

As expected, when the irrigation interval became longer (higher MAD percentage), the top soil layer dried out more, the proportion of water that is taken up from the deeper soil layers $(0.4-0.80 \mathrm{~m})$ increased, and less water in total was taken up [23].

\subsection{Plant Height}

The results showed significant differences between the treatments in plant height during the two cropping seasons in response to the different irrigation regimes for both ginger species (Figure 1A). African ginger showed statistically significant differences in plant height for treatments AG: 20-25\%, MAD, and AG: 60-65\% MAD (Figure 1B). The significant differences manifested from 100 days after planting to 240 days after planting for the first cropping season, while for the second seasons, the significant differences were revealed from 160 days after planting to 240 days after planting. The results showed an increase in plant height from 135 to 235 days after planting for the treatments of both ginger species. Taller plants were observed for all of the commercial ginger treatments when compared to those of African ginger in both seasons. For both ginger species, plant height at low to moderate water 
stress resulted in similar plant heights, while the severely stressed plants were stunted most. An earlier study on Satureja hortensis L. also reported decreased plant height in response to highly water stressed conditions [15]. Mofokeng et al. [17] also reported that the plant height of P. sidoides DC was reduced under severely stressed conditions as compared to the well-watered treatments. Mabhaudhi et al. [24] reported similar results for Bambara groundnut [24].
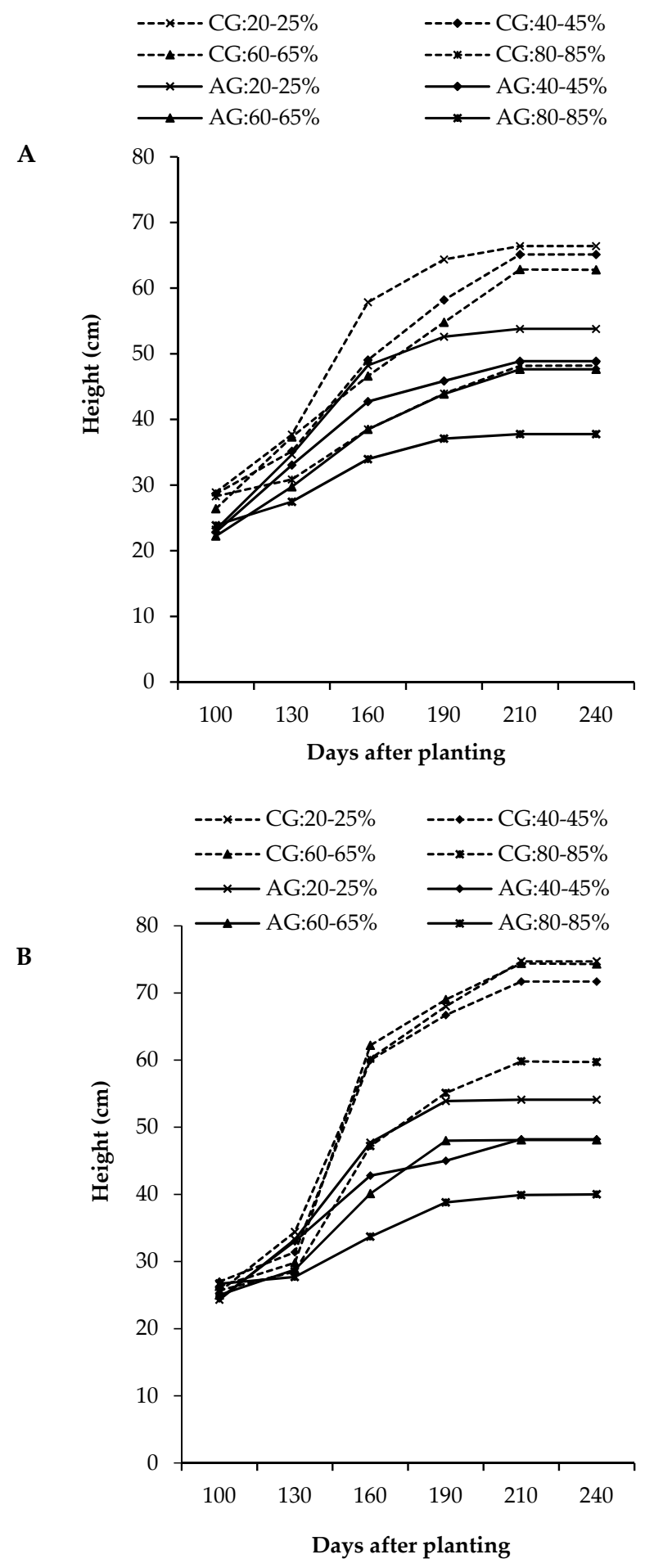

Figure 1. Plant height of two ginger species in response to different water regimes during the (A) 2015/2016 and (B) 2016/2017 cropping seasons. Where: CG: Commercial ginger; AG: African ginger; Vertical bars represent least significant difference $(\mathrm{P} \leq 0.05)$. 


\subsection{Stems per Plant}

Figure 2A,B represent the response of number of stems per plant to different water regimes over two cropping seasons for African and commercial ginger. The results indicate that there were significant differences between the stem numbers for different treatments. During 2015/2016 treatments CG 20-25\% MAD, CG 40-45\% MAD, and CG 60-65\% MAD showed significantly higher stem numbers from 130 to 240 days after planting (Figure 2A). It is notable that the three treatments of commercial ginger representing well-watered and intermediate water regimes did not result in any reduction in stem numbers. The higher stem numbers for these three treatments (CG 20-25\% MAD, CG 40-45\% MAD, and CG 60-65\% MAD) was apparent, as the availability of soil water improved plant growth. Since water plays an essential role in the physiological processes of plants [17], it can be deduced that the well-watered treatments enabled commercial ginger to maintain its normal physiological functions. Treatment CG 80-85\% MAD showed the lowest number of stems as compared to other treatments, irrespective of the ginger species (Figure 1A). Jyotsna et al. obtained similar results [25], who reported that water stress decreased growth and plant biomass of Salvia officinalis [26]. When severe water stress (treatment $80-85 \%$ MAD) was applied, the stem number declined more for both ginger species during both the 2015/2016 and 2016/2017 cropping seasons (Figure 2A,B), suggesting a strong effect on the development of the plant. Additionally, the first sign of water stress can often be detected by a reduction in cell turgesans and thereby a reduction in cell growth, especially in the stems and leaves.

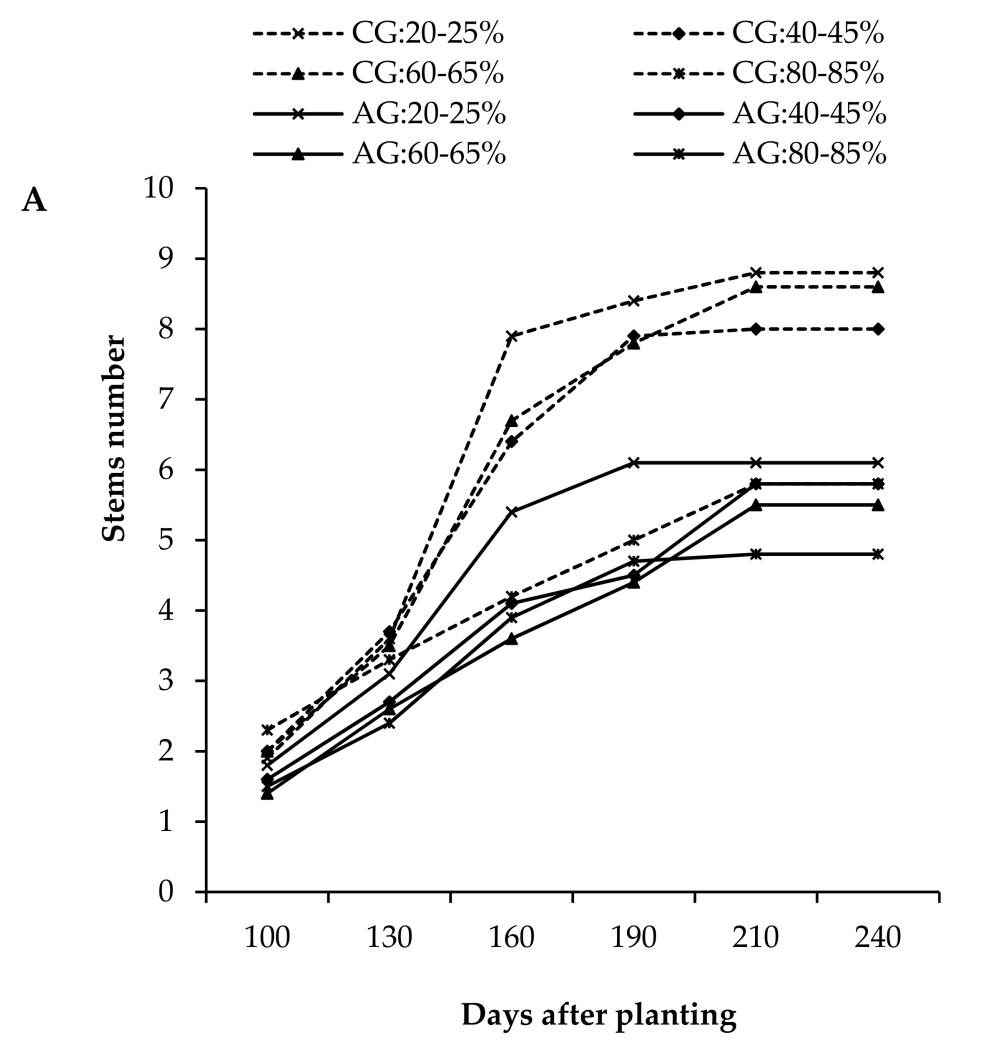

Figure 2. Cont. 


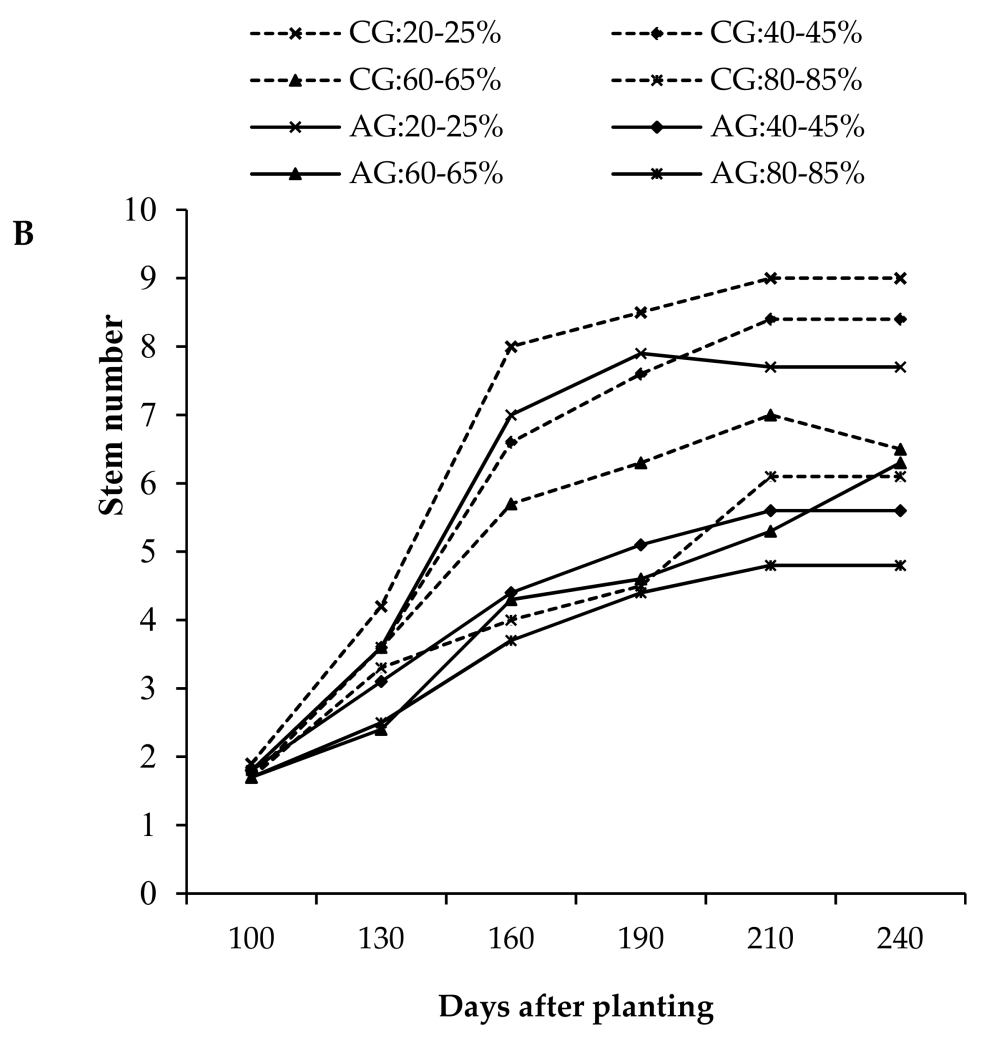

Figure 2. Number of stems per plant of two ginger species in response to different water regimes during the (A) 2015/2016 and (B) 2016/2017 cropping seasons. Where: CG: Commercial ginger; AG: African ginger; Vertical bars represent least significant difference $(\mathrm{P} \leq 0.05)$.

\subsection{Number of Leaves}

The results in Figure 3A,B showed the number of leaves per plant for commercial and African ginger, as affected by different irrigation regimes during 2015/2016 and 2016/2017 cropping season. The total number of leaves was much higher for treatment CG 20-25\% MAD during the 2015/2016 season (Figure 1A). The increases in the total number of leaves was more marked for well-watered and intermediate treatments (CG 20-25\% MAD, CG 40-45\% MAD, and CG 60-65\% MAD) than the severely stressed treatment (AG 80-85\% MAD) of African ginger for 2015/2016 and 2016/2017 season. The severely stressed treatment (AG 80-85\% MAD) that showed the least number of leaves during both seasons may have limited the development of the plants. The relatively low supply of water to the stressed treatments resulted in poor leaf formation and stunted growth. The number of leaves observed under the severely stressed treatment (CG 80-85\% MAD) are in agreement with the findings on the response of water stress on essential oil of oregano [27]. The severely stressed treatment (CG 80-85\% MAD) during 2015/2016 and 2016/2017 showed an intermediate number of leaves and it was not significantly affected by the restricted water supply. This result differs from the findings that were reported by Mofokeng et al. [17]. We posit that this result may have been due to an insufficient time of exposure to the severe stressed conditions. 


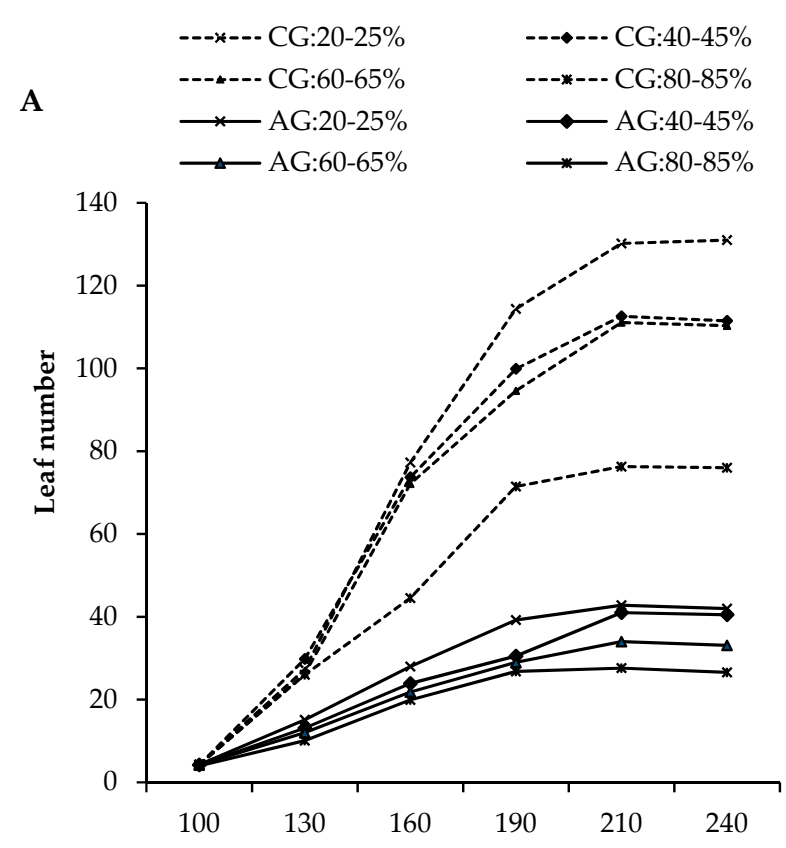

Days after Planting
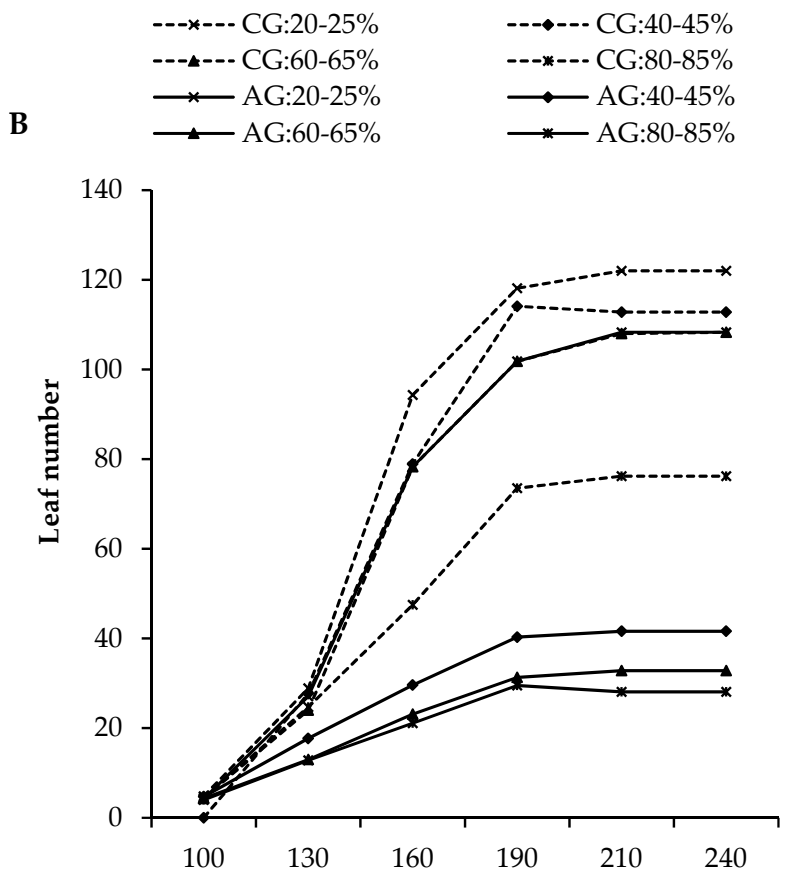

Days after Planting

Figure 3. Number of leaves per plant of two ginger species in response to different water regimes during the (A) 2015/2016 and (B) 2016/2017 cropping seasons. Where: CG: Commercial ginger; AG: African ginger; Vertical bars represent least significant difference $(\mathrm{P} \leq 0.05)$.

\subsection{Leaf Area Index}

The application of different irrigation regimes resulted in significantly different peak LAI values between treatments (Figure 4A,B). In 2015/2016, the leaf area index declined more under water stress conditions for African ginger than commercial ginger. In both seasons, the control treatment for African ginger species recorded the highest LAI of 3.1-2.2 $\mathrm{m}^{2} \mathrm{~m}^{-2}$, followed by the moderately 
stressed treatment (AG 40-45\% MAD) with 2.63-2.0 $\mathrm{m}^{2} \mathrm{~m}^{-2}$. The severely stressed treatment of commercial ginger (CG 80-85\% MAD) had the lowest LAI values of $0.8-1.2 \mathrm{~m}^{2} \mathrm{~m}^{-2}$. The lower LAI value under stress is a result of fewer and smaller leaves and a well-documented response to drought for many crops. The leaf area index responds to physiological processes, such as leaf expansion and photosynthesis, which are essential in dry matter production [28]. A previous study on the growth of $P$. sidoides in response to water and nitrogen level also revealed a decline in leaf area with water stress. Similarly, Acreche et al. [29] recorded the highest LAI for well-watered as compared to the stressed treatments of commercial ginger.

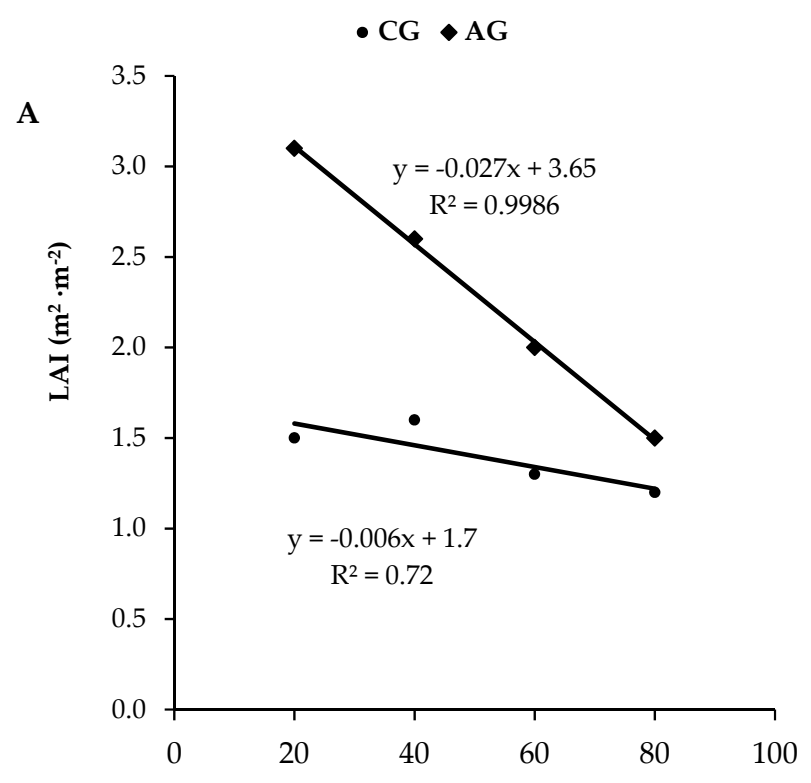

Maximum allowable depletion levels (\%)

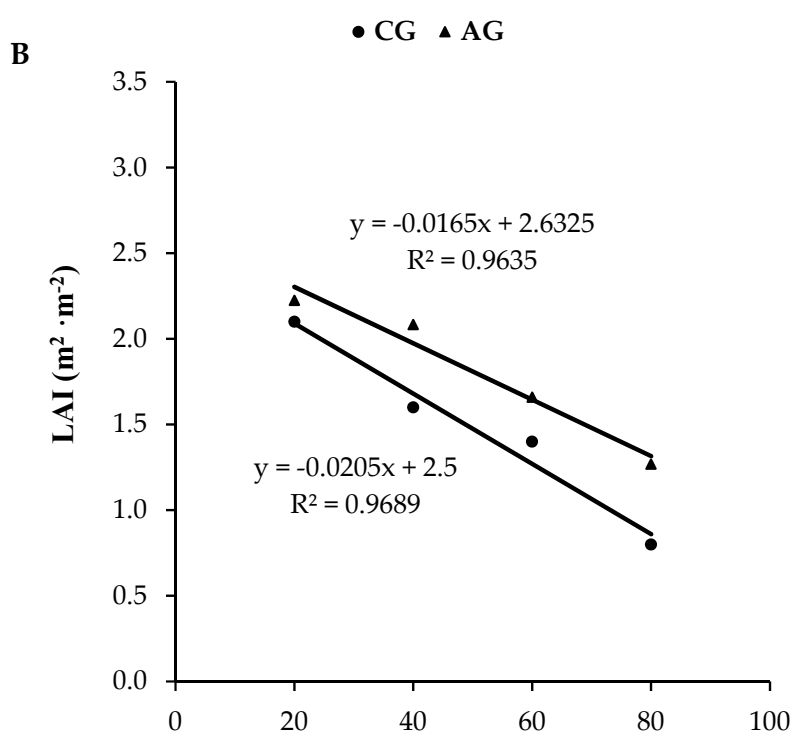

Maximum allowable depletion levels (\%)

Figure 4. Peak Leaf Area Index (LAI) values of two ginger species in response to different water regimes during the (A) 2015/2016 and (B) 2016/2017 cropping seasons. CG: Commercial ginger; AG: African ginger; $\mathrm{Lsd}=0.93$ and 0.53 for Figure A and B respectively. 


\subsection{Fractional Interception of Photosynthetically Active Radiation ( $F I_{P A R}$ )}

The fractionally intercepted photosynthetically active radiation $\left(\mathrm{FI}_{\mathrm{PAR}}\right)$ markedly varied between different irrigation regimes and the two ginger species (Figure 5A-D). The $\mathrm{FI}_{\mathrm{PAR}}$ for the well-watered treatment (20-25\% MAD) of both African ginger and commercial ginger generally showed the highest

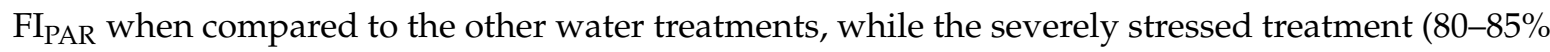
MAD) showed lowest $\mathrm{FI}_{\mathrm{PAR}}$ values. In most instances, commercial ginger recorded lower $\mathrm{FI}_{\mathrm{PAR}}$, values than African ginger at the same water treatments. The lower $\mathrm{FI}_{\mathrm{PAR}}$ values for severely stressed treatments (CG 80-85\% MAD) are likely associated with the smaller canopy of these plants. The higher $\mathrm{FI}_{\mathrm{PAR}}$ that was reported for African ginger as compared to commercial ginger is associated with the higher LAI recorded for African ginger in this study (Figure 4A,B).
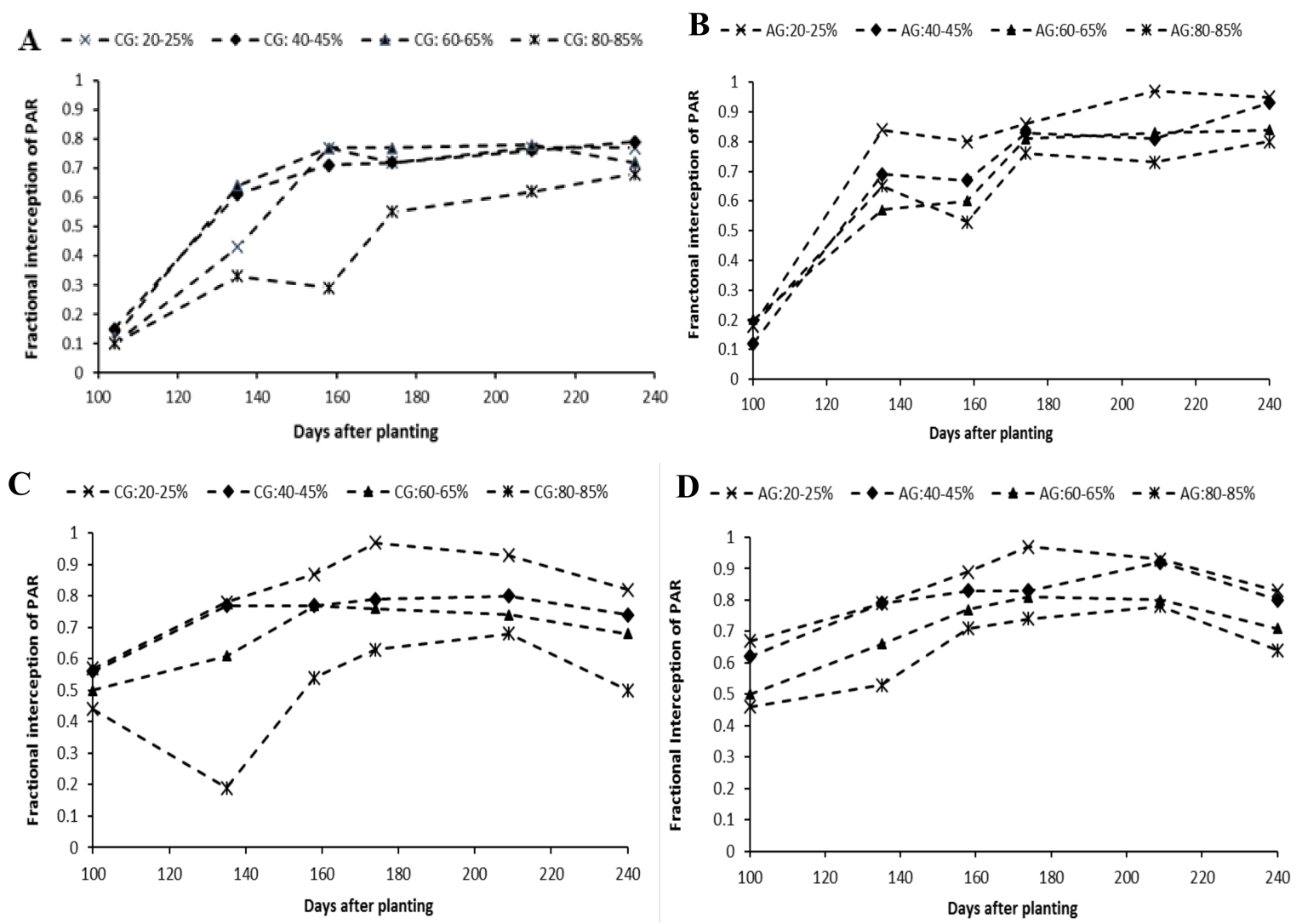

Figure 5. Fractional interception of photosynthetically active radiation $\left(\mathrm{FI}_{\mathrm{PAR}}\right)$ of two ginger species in response to different water regimes during the (A) CG: 2015/2016, (B) AG: 2015/2016, (C) CG: 2016/2017; and, (D) AG: 2016/2017 cropping seasons.

\subsection{Scanning Electron Microscopy (SEM) and Stomata}

Open stomata analyses describing the response of two ginger species, as affected by different irrigation regimes, are presented in Figures 6 and 7. Stomatal conductance of the well watered treatments was always significantly higher than that of the stressed treatments in most cases. The results show that the control treatment for commercial ginger had a total of 60 and 43 stomata per unit area in the two cropping seasons, respectively, while $95 \%$ of stomata were open in both of the cropping seasons. The moderately stressed treatment (CG + 40-45\% MAD) recorded $43.2 \%$ and $89.1 \%$ open stomata, respectively, in the two cropping seasons (Table 6). The control (unstressed treatment) and moderately stressed treatments had a higher number and higher percentage open stomata as compared to other commercial ginger treatments. For African ginger, the percentage of open stomata was higher for the control (CG + 20-25\% MAD) when compared to the rest of the treatments. The severely water stressed treatment (CG 80-85\% MAD) showed the lowest percentage of 
open stomata. The closing of stomata is associated with the inhibition of plant growth under drought stress, which may negatively affect crop yield [30]. Although treatment AG 60-65\% MAD recorded a higher total stomata number than other treatments of African ginger, less of the stomata were open, as compared to the control. The results indicate a trend of stressed treatments, resulting in lower stomata numbers per unit area and lower percentage open stomata in both ginger species (Table 6; Figures 6 and 7). African ginger generally showed more open stomata than commercial ginger. The opening and closing of stomata is regulated by the integration of environmental signals and endogenous hormonal stimuli [31]. In general, African ginger will lose more water through the open stomata under stress conditions than commercial ginger. This shows that African ginger has a less effective mechanism in preventing water losses though transpiration under drought than commercial ginger.

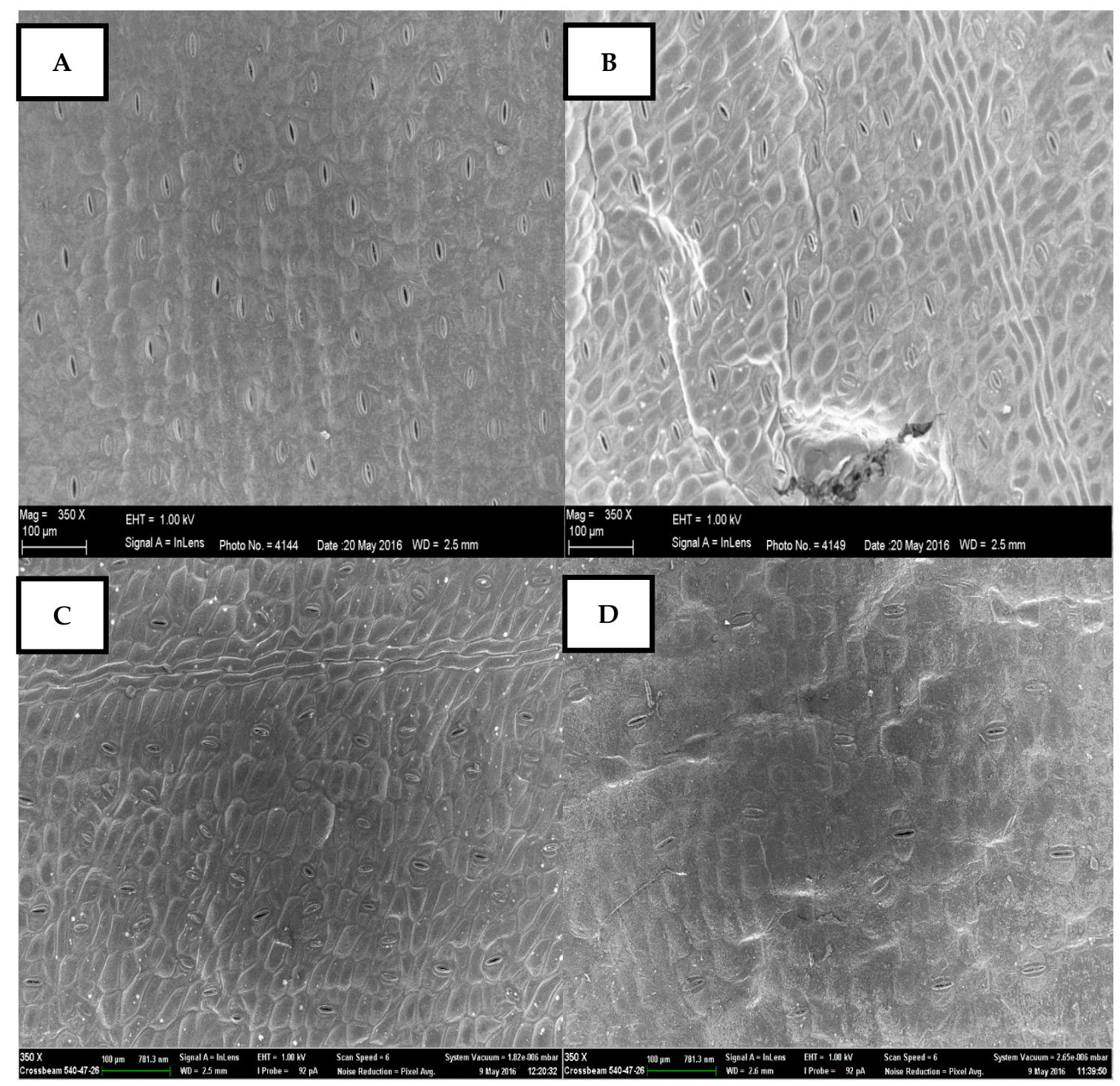

Figure 6. Scanning Electron Microscopy (SEM) images of open stomata pores of commercial ginger in response to different irrigation regimes during cropping season 2015/2016. (A) CG-20-25\% MAD; (B) CG-40-45\%MAD; (C) CG-60-65\% MAD; and, (D) CG-80-85\% MAD. 


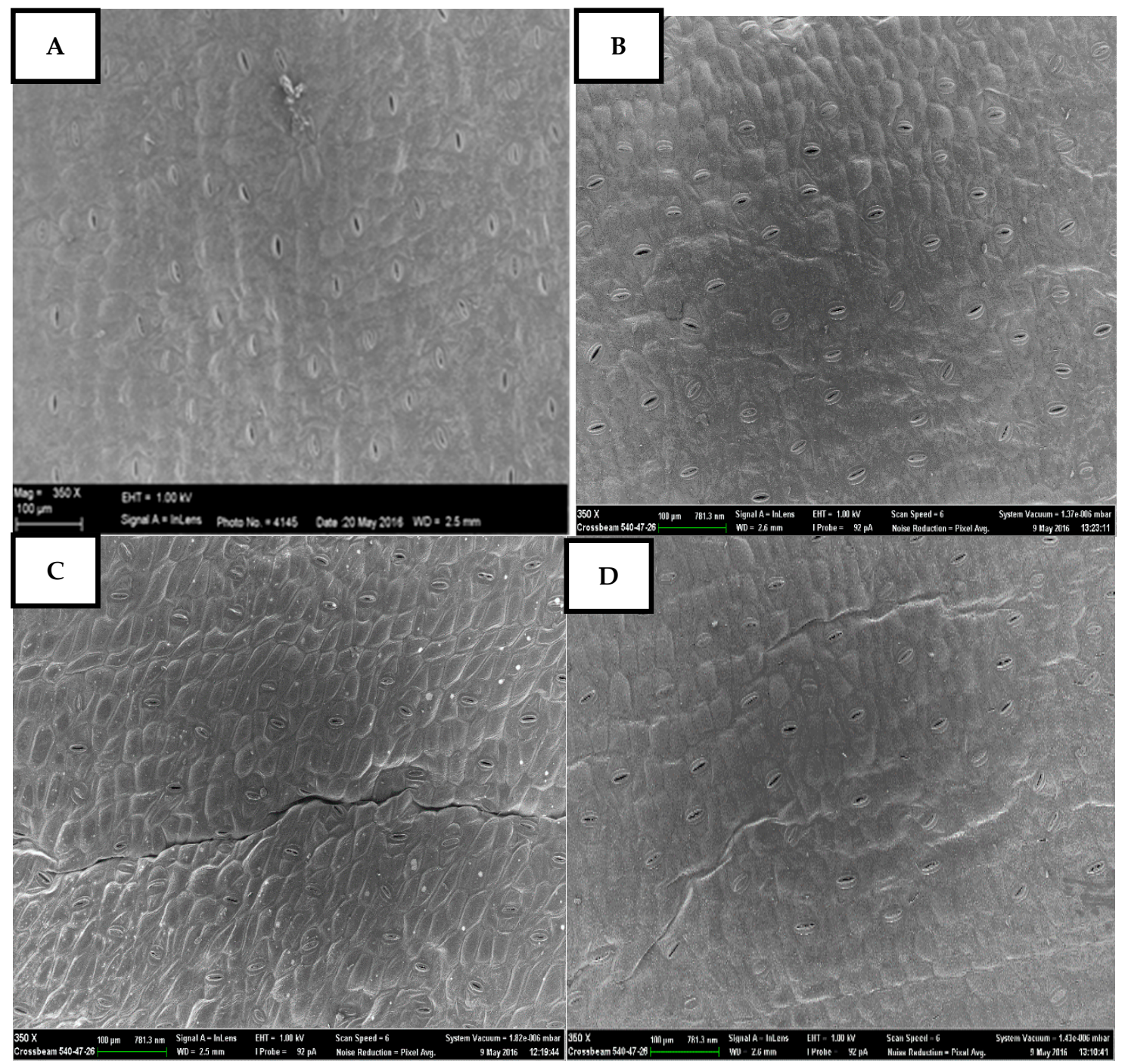

Figure 7. Scanning Electron Microscopy (SEM) images of open stomata of African ginger in response to different irrigation regimes during cropping season 2015/2016. (A) AG-20-25\% MAD; (B) CG-40-45\% MAD; (C) CG-60-65\% MAD; and, (D) CG-80-85\% MAD.

Table 6. Total number of stomata and open stomata per $10 \mathrm{~mm}^{2}$ in two ginger species, as affected by different irrigation levels in 2015/2016 and 2016/2017.

\begin{tabular}{|c|c|c|c|c|c|c|c|}
\hline \multirow{2}{*}{$\begin{array}{l}\text { Ginger } \\
\text { Species }\end{array}$} & \multirow{2}{*}{$\begin{array}{c}\text { Depletion } \\
(\%)\end{array}$} & \multicolumn{3}{|c|}{$2015 / 2016$} & \multicolumn{3}{|c|}{$2016 / 2017$} \\
\hline & & $\begin{array}{c}\text { Total } \\
\text { Stomata }\end{array}$ & $\begin{array}{c}\text { Open } \\
\text { Stomata }\end{array}$ & $\begin{array}{c}\text { Open } \\
\text { Stomata }(\%)\end{array}$ & $\begin{array}{c}\text { Total } \\
\text { Stomata }\end{array}$ & $\begin{array}{c}\text { Open } \\
\text { Stomata }\end{array}$ & $\begin{array}{c}\text { Open } \\
\text { Stomata }(\%)\end{array}$ \\
\hline \multirow{4}{*}{ CG } & $20-25$ & 60 & 57 & 95.0 & 43 & 40 & 93.0 \\
\hline & $40-45$ & 74 & 32 & 43.2 & 37 & 33 & 89.1 \\
\hline & $60-65$ & 49 & 24 & 48.9 & 18 & 6 & 33.3 \\
\hline & $80-85$ & 21 & 11 & 52.3 & 12 & 7 & 58.3 \\
\hline \multirow{4}{*}{ AG } & $20-25$ & 53 & 48 & 90.5 & 42 & 39 & 90.8 \\
\hline & $40-45$ & 57 & 45 & 78.9 & 42 & 36 & 85.7 \\
\hline & $60-65$ & 65 & 43 & 66.1 & 30 & 25 & 83.3 \\
\hline & $80-85$ & 47 & 32 & 68.0 & 30 & 7 & 23.3 \\
\hline
\end{tabular}

Where: CG: Commercial ginger; AG: African ginger. 


\subsection{Fresh and Dry Rhizome Yield}

The fresh rhizome yield showed significant variations $(p<0.05)$ between the two ginger species and different irrigation regimes (Figure $8 \mathrm{~A}, \mathrm{~B}$ ). The highest fresh rhizome yield was recorded for commercial ginger under well-watered conditions (CG + 20-25\% MAD and CG + 40-45\% MAD) for both of the cropping seasons (Figure 8A,B). Total fresh rhizome yield for commercial ginger increased from 15.7 to $43.5 \mathrm{t} \mathrm{ha}^{-1}$ as the water stress level decreased (Figure $8 \mathrm{~A}, \mathrm{~B}$ ). Well-watered plants also showed increased yield for African ginger, when compared to stress treatments. This was due to higher values of growth parameters, such as leaf number, stem number, LAI, and $\mathrm{FI}_{\text {PAR }}$ for the control treatments. However, stressed treatments reduced crop canopy, closed stomata, and it consequently resulted in lower photosynthesis, which eventually culminated in lower storage organ yield for both ginger species.

The differences in rhizome yield could mainly be related to the number of rhizomes per plant for the different species and water treatments. This emphasizes the importance of proper irrigation management to maximise yield at any given crop evapotranspiration level [32]. The effect of water depletion level on species under water stressed conditions showed that the maximum available depletion of less than $45 \%$ manifested in no differences in rhizome yield. An increase in the depletion level to $65 \%$ and higher resulted in a reduction of fresh rhizome yield. It is worth noting that the yield decrease in case of commercial ginger was gradual according to the water stress treatment, but in the case of African ginger, rhizome yield decreased almost half-fold when the MAD was raised from 20-25 to $40-45 \%$. During the second growing season, even when the MAD increased up to $80-85 \%$ MAD, the yield of commercial ginger was only reduced by about one-quarter, but in the case of African ginger, even a mild stress of $40-45 \%$ MAD reduced rhizome yield by half in both seasons. This confirms that African ginger is more susceptible to drought than commercial ginger. Similar results were reported for other drought sensitive crops, such as potato [9,33].

Similar to fresh rhizome yield, varying soil water contents at different irrigation treatments also had significant effects on dry rhizome yield (Figure 9A,B). Commercial ginger is sold either fresh for household consumption or dry as a flavourant in the food industry, while African ginger is used in the manufacturing of various medicinal products, for which dry rhizomes are usually used. The dry rhizome yield of AG seemed to be more consistent across seasons than CG. The total dry rhizome yields for commercial ginger ranged from 3.1-4.2 to 8.1-8.7 tha ${ }^{-1}$ for treatments $80-85 \%$ MAD and $20-25 \%$ MAD during the two cropping seasons, respectively. Figure 9A,B indicate that the dry rhizome yield for African ginger followed a decreasing trend from the well-watered treatment to the severely stressed treatment for both of the cropping seasons. Earlier studies on an onion crop also reported higher yields for the well-watered treatments as compared to the stressed treatments [34]. Severely stressed plants resulted in the lowest dry rhizome yield for both commercial and African ginger (Figure 9A,B). Reddy and Reddy reported similar results [13], indicating a reduction in the yield of peanuts with $80 \%$ depletion of available soil water. The higher yield for the control treatments in both of the ginger species was likely due to the observed increase in the number of leaves, which increased leaf area and photosynthesis capacity, as compared to the stressed treatments. A study of different irrigation regimes on the growth and yield of potato similarly revealed that total fresh and marketable tuber yield increased with an increasing amount of irrigation [35]. 


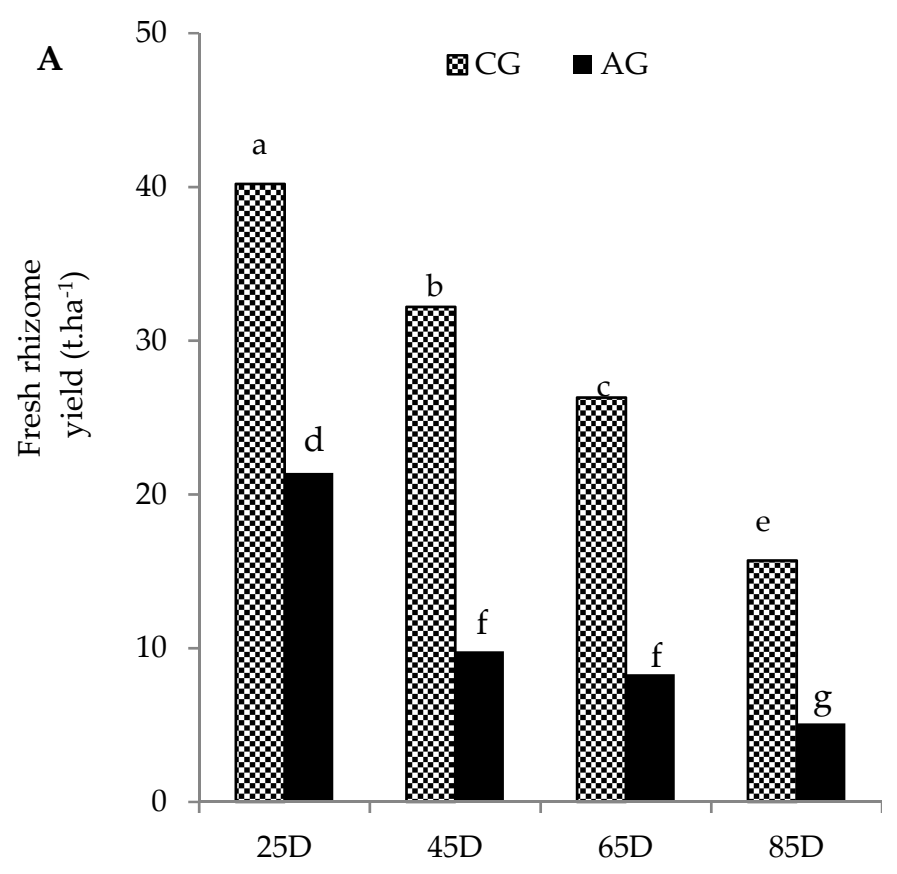

Maximum allowable depletion levels (\%)

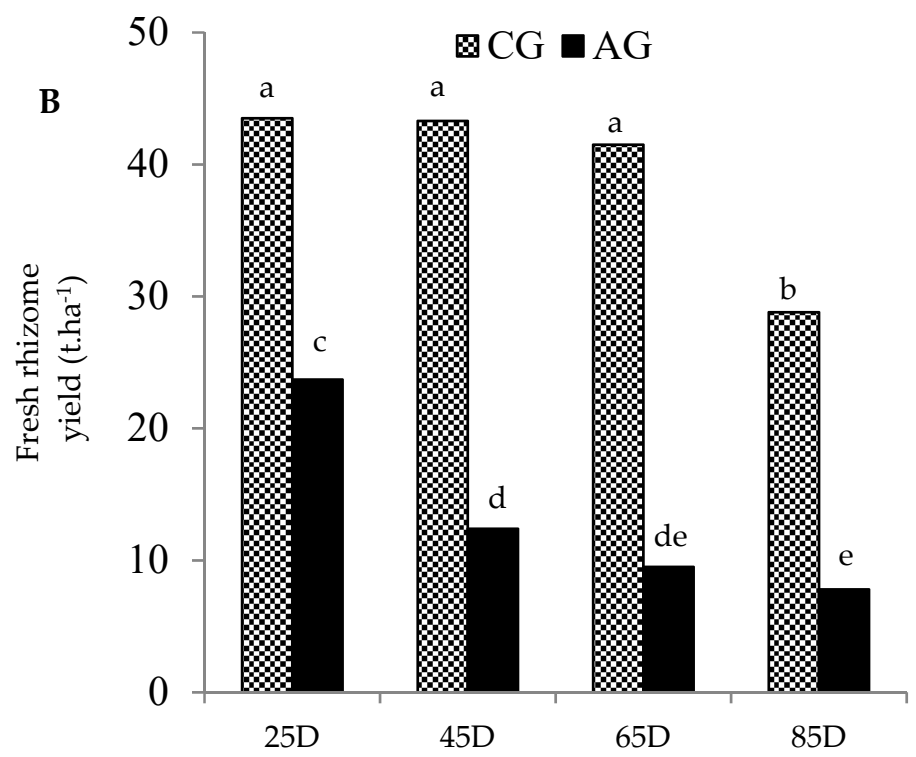

Maximum allowable depletion levels (\%)

Figure 8. Fresh rhizome yield $\left(\mathrm{t} \mathrm{ha}^{-1}\right)$ of African ginger in response to irrigation regimes during the (A) 2015/2016 and (B) 2016/2017 cropping seasons. Mean values followed by the same letter on the same bars are not significantly different at $(p \leq 0.05)$ level according to the Tukey's test. Where: CG: Commercial ginger; AG: African ginger; Lsd $=2.4$ and 4.6 for Figure A and B respectively. 


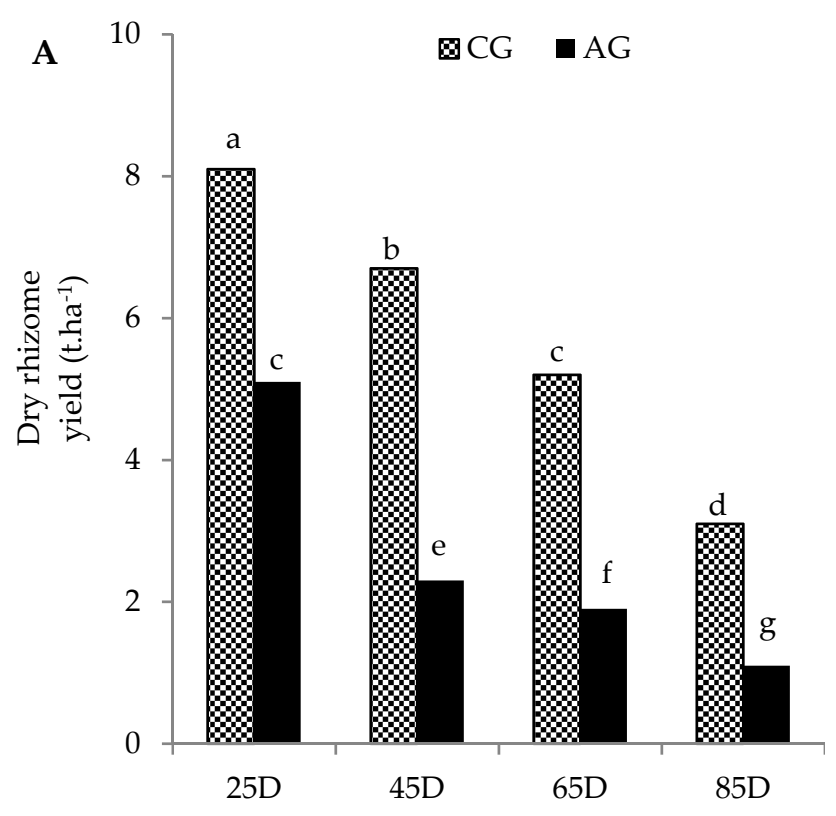

Maximum allowable depletion levels (\%)

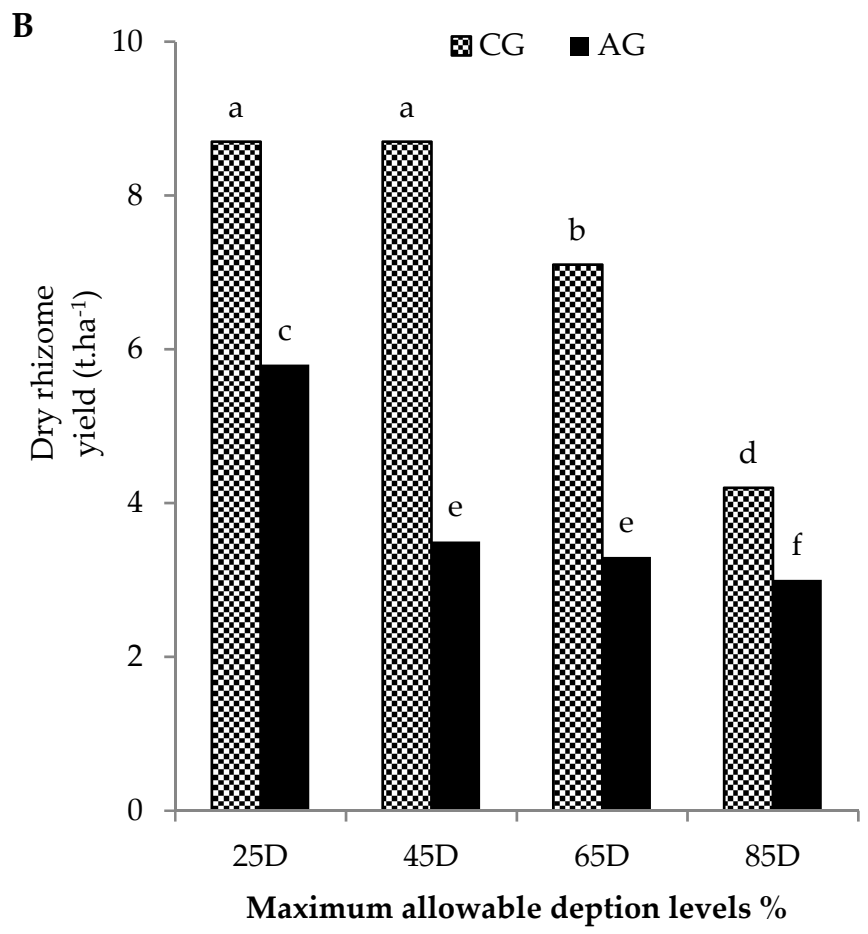

Figure 9. Dry rhizome yield $\left(\mathrm{t} \mathrm{ha}^{-1}\right)$ of African ginger in response to irrigation regimes during the (A) 2015/2016 and (B) 2016/2017 cropping seasons. Mean values followed by the same letter in the same bars are not significantly different at $(p \leq 0.05)$ level according to the Tukey's test. Where: CG: Commercial ginger; AG: African ginger; Lsd $=0.3$ and 0.2 for Figure A and B respectively.

\subsection{Water Use Efficiency}

Irrigation water use efficiency (WUE) is the relation between yield and water use, and it was calculated as the yield divided by the volume of water used. Table 7 lists the irrigation water use efficiencies for the different treatments. The maximum WUE values for commercial ginger were 
150 and $121 \mathrm{~kg} \cdot \mathrm{ha}^{-1} \mathrm{~mm}^{-1}$ for the less stressed treatment (CG-60-65\% MAD) in the two cropping seasons, respectively. Higher WUE values for moderately stressed treatments as compared to the well-watered treatment is common [27], and can be explained by the fact that the $40-45 \%$ and $60-65 \%$ MAD treatments used substantially less water, but they did not produce much lower yields than the control. Water use efficiency for African ginger was significantly lower in both of the cropping seasons, when compared to commercial ginger (Table 7). For African ginger, there was little variation in WUE between treatments, but the general trend was that the control and less stressed treatments had higher WUEs, which was opposite to the trend that was observed for commercial ginger. This is explained by the drastic drop in rhizome yield with the increase in water stress (an indication of drought sensitivity), while the corresponding decrease in water use was more gradual.

Table 7. Water use efficiency of commercial and African ginger in the 2015/2016 and 2016/2017 cropping seasons.

\begin{tabular}{|c|c|c|c|c|c|}
\hline & \multicolumn{3}{|c|}{$2015 / 2016$} & \multicolumn{2}{|c|}{$2016 / 2017$} \\
\hline & & Fresh & Dry & Fresh & Dry \\
\hline \multirow[t]{2}{*}{ Species } & Depletion & WUE & WUE & WUE & WUE \\
\hline & $\%$ & $\left(\mathrm{~kg} \cdot \mathrm{ha}^{-1} \mathrm{~mm}^{-1}\right)$ & $\left(\mathrm{kg} \cdot \mathrm{ha}^{-1} \mathrm{~mm}^{-1}\right)$ & $\left(\mathrm{kg} \cdot \mathrm{ha}^{-1} \mathrm{~mm}^{-1}\right)$ & $\left(\mathrm{kg} \cdot \mathrm{ha}^{-1} \mathrm{~mm}^{-1}\right)$ \\
\hline \multirow{4}{*}{ CG } & $20-25$ & $85.8^{c}$ & $17.3^{c}$ & $79.2^{b}$ & $15.9^{c}$ \\
\hline & $40-45$ & $113.5^{\mathrm{b}}$ & $23.8^{\mathrm{b}}$ & $119.4^{\mathrm{a}}$ & $24.1^{\mathrm{a}}$ \\
\hline & $60-65$ & $150.0^{\mathrm{a}}$ & $30.0^{\mathrm{a}}$ & $122.8^{\mathrm{a}}$ & $21.2^{b}$ \\
\hline & $80-85$ & $144.7^{\mathrm{a}}$ & $28.9^{\mathrm{a}}$ & $87.8^{\mathrm{b}}$ & $12.9^{\mathrm{d}}$ \\
\hline \multirow{4}{*}{ AG } & $20-25$ & $46.4^{\mathrm{d}}$ & $11.2^{\mathrm{d}}$ & $43.7^{c}$ & $10.7^{\mathrm{e}}$ \\
\hline & $40-45$ & $35.8^{\mathrm{d}}$ & $8.6^{\mathrm{d}}$ & $33.6^{\mathrm{cd}}$ & $9.2^{\mathrm{e}}$ \\
\hline & $60-65$ & $45.8^{\mathrm{d}}$ & $10.5^{\mathrm{d}}$ & $26.2^{d}$ & $9.2^{\mathrm{e}}$ \\
\hline & $80-85$ & $44.5^{\mathrm{d}}$ & $9.9^{\mathrm{d}}$ & $23.1^{\mathrm{d}}$ & $8.9^{\mathrm{e}}$ \\
\hline Lsd & & 15.5 & 2.8 & 16.5 & 1.9 \\
\hline
\end{tabular}

CG: Commercial ginger; AG: African ginger. ${ }^{*}$ Note: values followed by the same letter do not differ significantly at $\mathrm{P}=0.05$.

\section{Conclusions}

Our study has provided much needed information regarding the tolerance of ginger species to different levels of water stress. The amount of water use was higher under well-watered treatments as compared to stress treatments for both African ginger and commercial ginger. We have shown that growth and development parameter traits, such as height, leaf number, and stem number significantly varied between different species and irrigation treatments. Irrigation treatment effects on plant growth and development parameters depended upon plant species. The maximum LAI and FI PAR values of African ginger were higher than those of commercial ginger and this was reflected in both of the seasons. This was despite the fact that African ginger had less leaves, which thus reflects the bigger size of individual leaves of African ginger as compared to commercial ginger. Scanning electron microscopy images showed that both of the ginger species had more stomatal pores and open stomata under well-watered than stressed conditions. African ginger had a higher percentage of open stomata in all stressed treatments as compared to commercial ginger, suggesting limited stomatal control to prevent excessive transpiration losses under severe drought conditions.

Commercial ginger showed higher plant height, stem number, and leaf number, while African ginger had higher leaf area index and $\mathrm{FI}_{\mathrm{PAR}}$ when compared to commercial ginger. Fresh and dry rhizome yields were higher for commercial ginger as compared to African ginger in both seasons. Severely water stressed fresh and dry rhizome yields of commercial ginger were more affected than that of African ginger. Water use efficiency in terms of fresh commercial ginger yield was the highest at moderate water stress (CG-60-65\% MAD). For dry rhizome yield, the water use efficiency was highest for either CG-60-65\% or CG-40-45\% MAD. Based on the results of our research, we can conclude that water stress had a striking effect on the growth, yield, and WUE of ginger species. Finally, the study 
showed that severe water stress reduced ginger rhizome yield in both species. However, commercial ginger seems to be less sensitive to water stress than African ginger.

Author Contributions: D.M., M.J.S. and H.T.A. are the PhD supervisors of A.G. S.N.M., A.G. and M.M.M. contributed to fieldwork, methodology and formal analysis. All authors contributed immensely to writing and discussion of the final manuscript. All the authors approved the final manuscript for publication.

Funding: We are grateful to the University of Pretoria, the Agricultural Research Council (ARC), and the Oppenheimer Memorial Trust (OMT) for supporting this study, and to the National Research Foundation for the postgraduate bursary.

Acknowledgments: We thank Fortuna Company, for supplying the rhizome material used in this study and staff on the Hatfield experimental farm for technical support.

Conflicts of Interest: The authors declare no conflicts of interest.

\section{References}

1. Louw, C.A.M.; Regnier, T.J.C.; Korsten, L. Medicinal bulbous plants of South Africa and their traditional relevance in the control of infectious diseases. J. Ethnopharmacol. 2002, 82, 147-154. [CrossRef]

2. Okigbo, R.N.; Eme, U.E.; Ogbogu, S. Biodiversity and conservation of medicinal and aromatic plants in Africa. Biotechnol. Mol. Biol. Rev. 2008, 3, 127-134.

3. Mander, M.; Ntuli, L.; Diederichs, N.; Mavundla, K. Economics of the traditional medicine trade in South Africa: Health care delivery. S. Afr. Health Rev. 2007, 1, 189-196.

4. Van Wyk, B.E. A broad review of commercially important southern African medicinal plants. J. Ethnopharmacol. 2008, 119, 342-355. [CrossRef]

5. Okigbo, R.N.; Anuagasi, C.L.; Amadi, J.E. Advances in selected medicinal and aromatic plants indigenous to Africa. J. Med. Plants Res. 2009, 3, 86-95.

6. Mander, M. Marketing of Indigenous Medicinal Plants in South Africa: A Case Study in KwaZulu-Natal; Food and Agriculture Organization of the United Nations: Rome, Italy, 1998.

7. Dubey, N.K.; Kumar, R.; Tripathi, P. Global promotion of herbal medicine: India's opportunity. Curr. Sci. 2004, 86, 37-41.

8. Anjum, S.A.; Xie, X.Y.; Wang, L.C.; Saleem, M.F.; Man, C.; Lei, W. Morphological, physiological and biochemical responses of plants to drought stress. Afr. J. Agric. Res. 2016, 6, 2026-2032. [CrossRef]

9. Onder, S.; Caliskan, M.E.; Onder, D.; Caliskan, S. Different irrigation methods and water stress effects on potato yield and yield components. Agric. Water Manag. 2005, 73, 73-86. [CrossRef]

10. Magadza, C.H.D. Climate change: Some likely multiple impacts in Southern Africa. Food Policy 1994, 19, 165-191. [CrossRef]

11. Prasad, P.V.V.; Staggenborg, S.A.; Ristic, Z. Impacts of drought and/or heat stress on physiological, developmental, growth, and yield processes of crop plants. In Response of Crops to Limited Water: Understanding and Modeling Water Stress Effects on Plant Growth Processes; American Society of Agronomy: Madison, WI, USA, 2008; pp. 301-355. [CrossRef]

12. Galmés, J.; Flexas, J.; Savé, R.; Medrano, H. Water relations and stomatal characteristics of Mediterranean plants with different growth forms and leaf habits: Responses to water stress and recovery. Plant Soil 2007, 290, 139-155. [CrossRef]

13. Reddy, C.R.; Reddy, S.R. Scheduling irrigation for peanuts with variable amounts of available water. Agric. Water Manag. 1993, 23, 1-9. [CrossRef]

14. Ghasemzadeh, A.; Jaafar, H.Z.E.; Karimi, E.; Rahmat, A. Antioxidant activities, total phenolics and flavonoids content in two varieties of Malaysia young Ginger (Zingiber Officinale). Molecules 2010, 15, 4324-4333. [CrossRef] [PubMed]

15. Wilson, H.; Ovid, A. Growth and yield responses of ginger (Zingiber officinale Roscoe) as affected by shade and fertilizer applications. J. Plant Nutr. 2008, 16, 1539-1545. [CrossRef]

16. Jasim, B.; Joseph, A.A.; John, C.J.; Mathew, J.; Radhakrishnan, E.K. Isolation and characterization of plant growth promoting endophytic bacteria from the rhizome of Zingiber officinale. 3 Biotech 2014, 4, 197-204. [CrossRef] [PubMed]

17. Mofokeng, M.M.; Steyn, J.M.; Du Plooy, C.P.; Prinsloo, G.; Araya, H.T. Growth of Pelargonium Perlagonium sidoides DC. In response to water and nitrogen level. S. Afr. J. Bot. 2015, 100, 183-189. [CrossRef] 
18. Soil Classification Working Group. Soil Classification. A Taxonomic System for South Africa; Department of Agricultural: Pretoria, South Africa, 1991.

19. Panda, R.K.; Behera, S.K.; Kashyap, P.S. Effective management of irrigation water for wheat under stressed conditions. Agric. Water Manag. 2003, 63, 37-56. [CrossRef]

20. Fan, Y.; Wang, C.; Nan, Z. Comparative evaluation of crop water use efficiency, economic analysis and net household profit simulation in arid Northwest China. Agric. Water Manag. 2014, 146, 335-345. [CrossRef]

21. Tesfaye, K.; Walker, S.; Tsubo, M. Radiation interception and radiation use efficiency of three grain legumes under water deficit conditions in a semi-arid environment. Eur. J. Agron. 2006, 25, 60-70. [CrossRef]

22. Eiasu, B.K.; Steyn, J.M.; Soundy, P. Physiomorphological response of rose-scented geranium (Pelargonium spp.) to irrigation frequency. S. Afr. J. Bot. 2012, 78, 96-103. [CrossRef]

23. Zhang, Y.; Kendy, E.; Qiang, Y.; Changming, L.; Yanjun, S.; Hongyong, S. Effect of soil water deficit on evapotranspiration, crop yield, and water use efficiency in the North China Plain. Agric. Water Manag. 2004, 64, 107-122. [CrossRef]

24. Mabhaudhi, T.; Modi, A.T.; Beletse, Y.G. Growth response of a Bambara groundnut landrace to water stress. Afr. Crop Sci. Conf. Proc. 2011, 10, 97-102.

25. Jyotsna, N.; Ghosh, C.; Meitei, W.I. Study of growth, yield and quality of organically grown ginger varieties under rainfed condition of Manipur. J. Crop Weed 2012, 8, 17-21.

26. Bettaieb, I.; Zakhama, N.; Wannes, W.A.; Kchouk, M.E.; Marzouk, B. Water deficit effects on Salvia officinalis fatty acids and essential oils composition. Sci. Hortic. 2009, 120, 271-275. [CrossRef]

27. Said-AlAhl, H.A.H.; Omer, E.A.; Naguib, N.Y. Effect of water stress and nitrogen fertilizer on herb and essential oil of oregano. Int. Agrophys. 2009, 23, 269-275.

28. Blum, A. Drought resistance, water-use efficiency, and yield potential-Are they compatible, dissonant, or mutually exclusive. Crop Pasture Sci. 2005, 56, 1159-1168. [CrossRef]

29. Acreche, M.M.; Briceño-Félix, G.; Sánchez, J.A.M.; Slafer, G.A. Radiation interception and use efficiency as affected by breeding in Mediterranean wheat. Field Crops Res. 2009, 110, 91-97. [CrossRef]

30. Waraich, E.A.; Ahmad, R.; Ashraf, M.Y.S.; Ahmad, M. Improving agricultural water use efficiency by nutrient management in crop plants. Acta Agric. Scand. B 2011, 61, 291-304. [CrossRef]

31. Daszkowska-Golec, A.; Szarejko, I. Open or close the gate-stomata action under the control of phytohormones in drought stress conditions. Front. Plant Sci. 2013, 4, 138. [CrossRef]

32. Bekele, S.; Tilahun, K. Regulated deficit irrigation scheduling of onion in a semi-arid region of Ethiopia. Agric. Water Manag. 2007, 89, 148-152. [CrossRef]

33. Kirda, C. Deficit Irrigation Scheduling Based on Plant Growth Stages Showing Water Stress Tolerance; Food and Agricultural Organization of the United Nations: Rome, Italy, 2002.

34. Mulu, A.; Alamirew, T. Deficit irrigation application using center pivot sprinkler irrigation for Onion production. Int. J. Basic Appl. Sci. 2012, 1, 148-159.

35. Yuan, B.Z.; Nishiyama, S.; Kang, Y. Effects of different irrigation regimes on the growth and yield of drip-irrigated potato. Agric. Water Manag. 2003, 63, 153-167. [CrossRef]

(C) 2019 by the authors. Licensee MDPI, Basel, Switzerland. This article is an open access article distributed under the terms and conditions of the Creative Commons Attribution (CC BY) license (http:/ / creativecommons.org/licenses/by/4.0/). 